that they are always bountifully forthcoming. But the things which one really wants, the physical character of an alleged discrepancy, its numerical value, the so-many per cent of error under such conditions, - these one is left to wish for in vain, supposing that one has not long since learned to pay the personal growning for the personal satisfaction. So far as I am concerned, if I cuuld not adequately state how big a sin it is under which somebody else is staggering, I should prefer to hold my peace, believing that matters of rague conjecture are not fit to be chronicled. Nobody on the same side of common sense would to. day attempt to exhaust so complex a problem as the one in question in a single instance. It is reasonable, however, to try to remore pice by piece, element by element. What we did was an endeavor to remove the preponderating element, and I must re iterate that if our respite had not been cut short by recent unfavorable legislation, other things would have been brought out in their turn and in due time. Perhaps it is heresy to st ate that an immense future awaits laboratory research in physical geology ; but stating it, one would like to refer not so much to the punching of clay or the pulling of taffy candy, as to legitimate physical measurement However, others have survived eren the odium of cultivating "exact" methods. We are soothing ourselves with the comfort of so thinking.

CarL BarUS.

Phys. Laboratory. U. S. Weather Bureau, Washington, D. C.

\section{The Lac de Marbre Trout, A New Species.}

Description : B. 11 12; D. 13; A. $13 ;$ V. 9; P. 14; Vertebræ. 60 .

The specimen described is about twelve inches in length. Body subfusiform, compressed, pointed at snout, slender at the tail. Height of body near one-sixth of the total length; head one-fifth, crown convex. Snout one and one third, and interorbital space one and one-half times the eye. Eye little less than onefifth of the head, two-thirds of the space between the orbits on the forehead. Mouth large; maxillary straight, extending backward almost as far as the hinder edge of the eye, bearing strong teeth on its lower edge for nearly its entire length. Teeth on i. termaxillary and mandibles stronger. The tongue bears a series of four strong hooked teeth at each side, and behind the glossohyal on the basibranchials there is a band of several serits of smaller ones. Gill rakers straight, short, sharp, rough, $8+14$ on the first arch. Opercle thin, with a few striæ. Scales very small; apparently there are about two hundred and thirty in the series immediately abnve the lateral line and more than two hundred and fifty in a row fire or six scales above this. Distance from first ray of dorsal to end of snout little more than that from the same ras to the tip of the adipose fin. The middle of the total length falls half way between the ends of the hinder rass of the dorsal and its base. Dorsal and anal fins are slightly emarginate at the ends of their median rays. Pectorals and ventrals small; base of latter slightly behind the middle of that of the dorsal. Caudal pedicel slender, notch very deep, hinder bor 'er sinuous, as in Salmo alpinus, lobes pointed. The caudal notch is deeper in this species than in any other of the American forms except $\mathrm{S}$. namaycush.

Back dark brown with an iridescent blueish tint, unspotted. Dorsal dark, clouded, without spots or bands. Pectorals, anal and ventrals orange in the middle, sellowish or whitish toward bases and at their margins. The dark color of the back shades int, whitish tinged with pink below the lateral line. Ventral surface white, no doubt reddish in breeding seaso.. Head black on top. silvery on the cheeks; white beneath. Flesh pink. Caudal tin yellowish toward the base, brown toward the hinder border, which has a narrow edying of light color. Faint areas

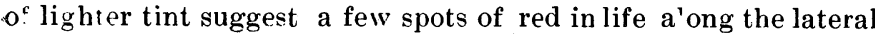
line; the condition of the specimens is such that this may be left in question, as also the number of caeca or presence of parrbands of which there are faint indications

This fish is evidently allied to the blue-back of the Rangeley Lakes, S. oquassa, but reaches a greater size than that species, and is readily distinguished by the maxillary and its dentition, the caudal tin, and the coloration. Similarly when compared with $\mathrm{S}$. arcturus, S. słagnalis and S. Rossi, it is seen to be quite distinct. With the saibling, S. alpinus, introduced in Sunapee Lake and elsewhere, it has still less in common.

Our specimens were taken in Lac de Marbre, Ottawa County, Province of Quebec, Canada, whence they we e sent by favor of the Hon. J. G. A. Creighton. They reached us at the instance of Mr. A. N. Cheney, fishing editor of Shooting and Fishing, who when asked to suggest a specific name replied with the question, "How would it do to name it for Mr. R. B. Marston, editor of Fishing Gazette, London, an Englishman orerflowing with good feeling for everything pertaining to fish. fishing and America, and who is doing much to enhance friendly interest between the people of the two countries?" In consequence of the suggestion this handsome char, one of the handsomest of our species, is introduced under the name, Salmo (Salvelinus) Murstoni.

Mus. Comp. Zool., Cambridge, Mass.

S. Garman.

\section{Tucumcari.}

THE writer first visited this historic locality in 1887 , before he had had opportunity to define the Denison beds at the top of his Lower Cretaceous section in northern Texas, and fell into the error, which others have not escaped, of concluding, from the peculiar Jurassic-like Gryphoea dilatata, Marcou, the only fossils found upon that visit, that the beds were Jurassic, and so published his opinion.

Later, howerer, after having had an opportunity to complete his study and arrangement of the stratigraphy of the Comanche series in central Texas, he discovered in the Denison beds ${ }^{1}$ of his Washita Dirision certain features which Jed him to believe that his early diagnosis of the Tucumcari beds was erroneous, and that they were really closely allied in age to the Denison beds. Under this impression, which was communicated orally to all interested, he availed himself of the first opportunity to revisit Tucumcari, A pril 30, 1891. He then discovered in association with G. dilatata the list of additional species berewith given, and, at earliest opportunity, under date of May, 1892, published, in a general discussion of the region, the following revision of his previous conclusions, which was the first printed announcement of the Cretaceous age of the $G$. dilatata beds: -2

\section{"The Trinity Sands and Red Bed Regions.}

"The writer has twice visited the Mesa Tucumcari and found it a most interesting geological remnant of the former area of the Llano Estacado. The table or sum nit described by Capt. Simpson is covered with the typical Llano Estacado formation, identical in composition and formerly continuous with the sheet which covers the Llano proper, some 20 miles distant. Below this is a vertical escarpuent of 50 feet or more of typical Dakota sandstone resting upon loo:e sands and clays, forming a slope identical in aspect and fossil remains with the Denison beds of the Washita Division, which have been eroded away from the 400 miles intervening between it and the main body of those beds at Denison, Texas. Beneath this is a large deposit of the typical Trinity sands country ${ }^{3}$ of white pack sands, thin clay seams and flagstones, while the base is composed of the typical vermilion sandy clays of the Red Beds."

Notwithstanding the above clear statement of my opinions, the Third Annual Report of the Geological Survey, printed nearly a half-year afterward, devotes many pages to asserting that $I$ held to the Jurassic age of the $O$. dilatata beds at Tucumcari. Upon pointing out this misquotation, instead of acknowledging the error, and repairing the injustice, it was followed up by a prirately

1 Denison beds as originally defined and used by writer. Not the Dentson beds of Taff, as used in an entirely different meaning. Compare Bulletin of Geological Society of America, Vol. ri., p. 591, and Thtrd A:nual Report of Texas State Geological Survey.

2 "On the Oscurrence of Artesian and Other Underground Waters in Texas, Eastern New Mexico, and Indian Territory West of the 97th Meridian," Texas, Eastern New Mexico, and Indian Territory West of the 97th Merldian,"
by Robert Thomas Hill (being part of Vol. III of Senate Document 41, 1st by Robert Thomas Hill (being part of Vol.
Session, 52d Congress, Washington, May, 1892

s For "country of " read "consisting of "- a typographic error. 
printed, bitter, and vindictire attack upon my report, endeavoring to discredit all the work $I$ had done in the Texas region. This last-mentioned paper is so utterly incorrect in its assertions, and so malicious in tone, that $I$ do not think it needs other answer than a perusal of it. Certainly it has no place in scientific literature, and if any of my friends should be so deceived by it as to believe any of its assertions, I shall be glad to clear any doubts by correspondence.

In Science of May 26, 1893, p. 283, the author of the foregoing attacks again misquotes me by saying that after my second visit to Tucumcari I again affirmed Marcou's reference, an assertion which has no foundation, for hardly had the two lives after my first visit been printed before I realized my mistake, and orally communicated it to everyone interested, and have never since maintained by word or pen, and was the first to publish the true age of these beds.

It was impossible, in a general report written upon the subject of Artesian Water, to go into controversy over the age of a fossiliferous horizon. I had given a full outline of the region with its hroader problems in a Bulletin of the Geological Society of America for 1891, entitled "Notes on the Texas New Mexico Region." In this paper I clearly set forth the Tertiary age of the Llano Estacado, and amplified many points which have since been published entirely de novo. Inasmuch as several parties have criticised me in public print for not giving the minutiæ of Tucumcari, I submit the following amplification of my previous remarks, and hope it will prove satisfactory to all fair-minded readers.

\section{Preliminary.}

\section{Section of Tucumcari Mesa.}

6. Summit of Mesa (Neocene). White, calcareous, silicious, marly limestone of character peculiar to Tertiary formations of Great Plains......................... 25- 50

5. Escarpment around summit of Mesa (Dakota). Consisting of the massive brown-yellow sandstone, which I had traced for days from LaMora, and other points on the Las Vegas Plateau, and which Stevenson had called (I think properly) Dakota. Estimated to be about....................

4. Crumbling yellow sandetone at base of above, and (4a). Gentler slope, forming bench around summit escarpment, (Washita) Division of Comanche series. Decomposing sandstone of base of 4 , and arenaceous clays and marls. Containing fauna of Denison beds, Washita Division at top, and G. dilatata, Marcou, in debris, apparently weathered out....

3. Shoulder at base of above.

Impure, yellow, arenaceous stone.............

Pedestal, or lower slope of Mesa.

2a. Upper part (Trinity).

White and red unconsolidated sands (pack sands), with thin strata of dimension-layers of hard quartzitic rock, and thin layers of blue clay, resembling in general character the Potomac sands of Maryland and the Trinity Sands of Texas. This horizon contains a peculiar granular mineral, resembling red coral, and outcrops in all the escarpment of the Las Vegas Plateau on the north side of the Canadian, and is denominated the white band in that region, to distinguish it from the brown band (Dakota) and underlying Red Beds.............

1(b) Lower portion of slope (Pre-Cretaceous). Bright, vermilion, argillaceous clays of the Red Beds continuing to bed of Canadian............

The above section is not final or complete in details of the individual beds, but it illustrates the sequence of the four great formations as preserved at Tucumcari and in the adjacent Llano Estacado, and shows the geologic position of the following fauna, which 75 were collected near the summit below the base of the sandstone escarpment which surrounds it, in beds numbered 4 and 4a.

List of Fossils.

1. Turbinolia texana, Conrad. United States and Mexican Boundary Survey.

2. Ostrea (Gryphcea) dilatata, Marcou. Geology of North America.

3. Ostrea quadricostata, Shumard. Transactions Academy of Science, St. Louis, 1860.

4. Plicatula, species undescribed.

5. Neithea occidentalis, Conrad. United States and Mexican Boundary Survey.

6. Trigonia emoryi, Conrad. United States and Mexican: Boundary Survey.

7. Protocardia multistriata, Con. United States and Mexican Boundary Surrey.

8. Turritella marnochii, White, or Seriatim granulata, Roemer.

9. Ammonites leonensis, Conrad. United States and Mexican Boundary Survey.

In addition to the above there are four species of Pelecyopoda, which I am unable to determine generically, but they resemble Astarte, Lucina, Panopcea, and Isocardia.

All of the species enumerated, with the exception of No. $2(G$. dilatuta, Marcou), occur elsewhere in the greatest abundance and similarly associated in the Washita Division of the Comanche Series of Texas and Mexico, and, with the exception of Nos. 5 and 8 , have never been found in any other beds than those of the Washita Division. Nos. 5 and 8 range down ward into the Fredericksburg Division.

No. 1 (Turbinolia texana Con.) has not been reported east of the Pecos, but it occurs near El Paso, and at Arivichi. Sonoras (as shown by (Gabb), associated with a fauna simlar to that of Tucumcari.

The furms from No 2 tu No. 9, inclusive, are the most common and characteristic species of the Washita Division, and can be collected at nearly any locality where the entire division is $\in \mathrm{X}$ posed, between Marietta, Indian Territory, and the Rio Grande.

The ammonite is the common, characteristic ammonite of the Fort Worth beds of the Washita Division, at Denison, Fort Worth, Austin, and elsewhere, and has hitherto not been found except in the Fort Worth beds of the Washita Division.

Ostrea quadricostata, Shum., Trigonia emoryii, Con., and the other species mentioned are especially characteristic of the Denison or uppermost beds of the Washita Division, at Denison, an 1 bence my reference of these beds at Tucumcari to the Denison beds of the Washita Division.

As I have preriously maintained, G. dilatata, Marcou, is a good species, entirely distinct from $G$ pitcheri, Morton, and, as has been said, has remarkakle resemblance to the Jurassic G. d.latata of Sowerby. Under these conditions it is not strange, then, that before the stratigraphic and paleontologic position of the Washita Division was known, that the distant Tucumcari beds should bare been adjudged Jurassic upon the evidence of the two species collected therefrom by Marcou, which certainly have, when considered alone, a most Jurassic aspect. ${ }^{1}$

The section and list of fo:sils above given differ in detail from those published on page 208 of the Third Annual Report of the Texas State Geological Survey. The two lists, how erer, bot h thow the Gryphoea dilatata beds to be of the age of the Washita Dirision of the Comanche Series, and the author of the Texas report, which was printed several months after the writer's, came to the same conclusion, although he seems to hare been unaware of the fact that the writer had abandoned bis early reftrence of the $G$. dilatata beds to the Jurassic. With the exception that the beds which the writer refers to the Trinity, are referred by the Texas auth $\mathbf{r}$ to the Triassic, there is no dissimilarity between their conclusions.

Following is the list of fossils published in the Texas reports, "collected from the Tucumcari beds in the vicinity of Tucumcari

1 Gryphcea dilatata, var. tucumcari, Marcou, and O. marshi, Marceu. 
and Py ramid Mountains." It is unfortunate that the exact locality of the collection is not giren:-

Gryphoea dilatata var. tucumcari, Marcou.

Ostrea marshii, as determined by Marcou.

Gryphoea pitcheri, Morton,

Exogyra texana, Roemer.

Ostrea quadriplicata, Shumard.

Trigonia Emoryii, Conrad.

Cardium hillanum, Sow.

Cytherea leonensis, Conrad.

Turritella seriatim granulata, Roemer.

Pinna, Sp.

Ammonites.

Pecten.

Finally, the writer wishes to state that he is not prepared, nor does he desire, to write a final treatise on the Tucumcari, which can never be properly related until the atlas-sheets of the United States Geological Survey are completed for the region. Tucumcari is but a single station in the vast group of phenomena belong. ing to the deposition and degradation of the Las Vegas and Llano Estacado Plateaus and the Canadian Valley, and to be properly understood, it would be necessary to write a treatise on the whole region. One thing is settled besond all doubt in my mind, however, and that is that the $G$. dilatata beds of the region do not belong to the Jurassic, but are undoubtedly of Cretaceous age. On the other hand, it may also be safely assumed that the Gryphoed dilatata, Sow , of Marcou, is not the same as G. pitcheri, Morton, as has been asserted by many authors, nor does it occur in the Cretaceous beds of central Texas, so far as the writer is aware. But this is a question which cannot be discussed intelligibly until a thorough revision of the Gryphæas is made.

In conclusion, permit me to say that there is not one trace of the Jurassic formation over the Texas region, as Mr. Marcou so positively affirms, and, furthermore, that there is no eridence that it was ever there, the whole trend of the testimony being to show that that region was land during the Jurassic period.

If the writer should devote his time to criticișing the works of his contemporaries or predecessors, he would have little time for research. It has been my practice, however, under the opinion that all knowledge is progressire, to see the good in the works of others, and to correct any errors without abuse. In all I bave published on the Texas region, there is not a line which was written with the desire to discredit any man, and yet $I$ believe that my severest critics will ccnfess that there has been great advance in opinion since I undertook the renaissance of geologic study in Texas.

My collections from Tucumcari are in Washington, and are open to the inspection of anyone inter sted.

ROBT. T. HILL

\section{Chloropia.}

THE case of Wallian, reported on page 360 of the latest volume of Science, would seem to be one of temporary Chloropia. More extended and carefully recorded observations, while the observer is looking at various objects under various conditions, would be very desirable.

Yale University, New Haven.

\section{Trees as a Factor in Climate.}

I ONCE observed a signal case of the effect of trees in determining rainfall. A few years ago I was walking along a road in the so-called backbone of England at an elevation of from 800 to 1,000 feet above the sea-level. It was a dull, calm October day, and the hills on either side were cased in mist. Where I was no rain was falling and the ground was quite dry. As I passed on the road entered and traversed a wood of fir trees. Here I at once encountered a gentle drizzle. Far from suspecting that the trees were playing any part in the matter, I concluded that the expected wet weather had at last set in. When the road emerged from the rood at its opposite extremity I found that no rain was there falling or had fallen. Still I did not connect the trees with the downfall, but imagined that the weather had again improred.

On returning from my destination about three hours after- wards I found that the rain was still falling in the wood, but that it ceased as soon as I emerged into the open country. The ground, too, within the wood was wet, still all around it was dry. Hence it appeared that a slight rain must have been falling for the greater part of the day within the wood, but not in the bare fields and heath land outside.

Thus under certain conditions of the weather the presence of trees may determine rainfall which would not take place in their absence.

London, England. J. W. Slater.

\section{Mineral Wax.}

I notice an account and inquiry in Science of June 16 in regard to the receipt at the National Museum of specimens of natural wax coming from Portland, Oregon, derived from the shores of the Columbia River, and from other accounts it is found along the coast from the Columbia River to Puget's Sound.

The material has been well known for the past half century as mineral wax, native paraffin, ozokerite and lastly as ozocerite, a hydro-carbon compound (hydrogen, 15 per cent; carbon, 85 per cent-variable); supposed to be derived from bituminous and lignite coal formation by infiltration and crystallization. It is generally found in situ in the neighborhood of coal and lignite beds and in the bituminous clays or shales.

The legend as to its being derived from a wreck is a most absurd one. It is a resinous wax in consistency and translucency, with structure sometimes foliated; color brown or sellowishbrown by transmitted light; leek green by reflected light; odor, aromatic, in specimens that I bave examined, having the characteristics and feel of beeswax that had been lying for some time in water.

It is mined in variable quantities in Germany, Austria, Turkey, and England, associated with the soft coal and lignite beds.

In Galicia alone about 30,000 tons have been mined since its discovery there in 1859. It is used in Europe principally in the manufacture of candles and by refining in place of beeswax and paraffin. It is said to be an excellent electrical insulator.

In the United States it is mined in situ at Soldiers Summit, Uintah County, and in Emery County, Utah. Sixty-five thousand pounds were marketed in 1888 , with a yearly increasing output. The whole product of the United States in 1890, including the Oregon find, reached 350,000 pounds.

The imports of mineral wax, ozocerite, under the names of bay or myrtle, Brazilian and Chinese wax, in 1890 were over one and a half million pounds.

It has been found in situ in thin seams in the lignite beds of Oregon, Washington, and British Columbia. The deposits along the Columbia River and on the sea-shore of Oregon are no doubt the debris from lignite beds near by. 361 Broadway, New York.

\section{BOOK-REVIEWS.}

The Seismological Journal of Japan. Edited by John MILne, F.R.S.

IN 1880 the Seismological Society of Japan was founded by a number of earnest students of seismology in that country, prominent amongst whom was the editor of this Journal. In the earlier years of its existence is membership included such well-known names as Milne, Gray, Ewing, Mendenhall and others at that time resident in Japan, and their interest in the science led especially to the invention of many instrumental appliauces for the study of earthquake phenomena, some of which have been copied wherever earthquakes are observed, and in some respects have revolutionized the science of experimental seismology. It also resulted in the establishment of a chair of seismology in the Imperial University of Japan, and the organization of a bureau controlling a central observatory and some 700 outside stations. Of late years, however, the interest in the society bas declined, partly through the return of some of its most active supporiers to England and America, and, after publishing sixteen rolumes of Transactions, in 1892 the society ceased to exist. Professor Milne, howerer, still remains in Japan and has determined to continue the publication of seismological literature in the present 